\title{
Corporate Governance and Firm Financial Performance: Do Ownership and Board Size Matter?
}

\author{
Adeusi, Stephen Oluwafemi Ph.D \\ Department of Banking and Finance, Faculty of Management Sciences, \\ Ekiti State University, Ado Ekiti, Ekiti State, Nigeria. \\ Email:ogamisir2005@yahoo.com
}

\author{
Akeke, Niyi Israel \\ Department of Business Administration, Faculty of Management Sciences, \\ Ekiti State University, Ado Ekiti, Ekiti State, Nigeria. \\ Corresponding Email: ninikx2002@yahoo.com
}

Aribaba, Foluso Olugbenga

Centre for Distance Learning, Obafemi Awolowo University, Ile-lfe, Nigeria. Email: folusoaribaba2003@yahoo.com

Adebisi, Obawale Simeon

Department of Business Administration, Faculty of Management Sciences Ekiti State University, Ado-Ekiti, Nigeria

Doi:10.5901/ajis.2013.v2n3p251

\section{Abstract}

Using a sample of 10 selected banks annual reports covering 2005-2010, this study examines the relationship between corporate governance and performance in Nigeria banking sector. Based on the econometric model, the result indicates that improved performance of the banking sector is not dependent on increasing the number of executive directors and board composition. It shows further that when there are more external board members, performance of banks tends to be worse. The study concludes a need for increase in board size and decrease in board composition as measured by the ratio of outside directors to the total number of directors in order to increase the bank performance.

Keywords: corporate governance, performance, corporate fairness, transparency, accountability

\section{Introduction}

The International financial landscape is changing rapidly; economies and financial systems are undergoing traumatic year, globalization and technology have continuing speed, financial arenas are becoming more open, new products and services are flooding the market and regulators everywhere are scrambling to assess the changes and master the turbulence (Matama, 2008). Mergers and acquisitions are now trends to make financial operators remain in business. One fact remains that cannot be changed is the need for countries to have sound resilient banking systems and strong banks with good Corporate Governance that will use competition to strengthen and upgrade their institutions for survival in an increasingly open environment (Kaheeru, 2001).

Corporate governance is about promoting corporate fairness, transparency and accountability (Financial Times, 1999). Hence, factors responsible for poor corporate performance especially in banks emanate from lack of transparency, accountability and poor ethical conduct (Kibirango, 2002). Governance is a requisite for survival and a gauge of how predictable the system for doing business in any country is. In developing countries, the importance of governance is to strengthen the foundation of society and chip into the global economy (Matama, 2008).

Corporate governance is about putting in place the structure, processes and mechanisms that ensure that the firm is being directed and managed in a way that enhances long term shareholder value through accountability of managers 
and enhancing firm performance. In other words, through such structure, processes and mechanisms, the well-known agency problem (which results when those who own the business are separated from those who manage it thus leading to conflict within the firm) may be addressed such that the interest of managers can be aligned with those of the shareholders. The agency problem arises from the relationship between the person who owns a firm and the person who manages or controls it. For instance, investors or financiers (principal) hire managers' (agents) to run the firm on their behalf. Investor needs managers specialised human capital to generate returns on their investment and managers may need the investors' funds since they may not have enough capital of their own to invest. In this case there is a separation between the financing and the management of the firm i.e. there is a separation between ownership and control (Berle and Means, 1932).

The crisis of confidence that had rocked nations' banking sector alerts government to the importance of maintaining efficient corporate governance mechanism to ensure stability of the economy. Hence, regulators and researchers attention have turned towards investigating the impact of the corporate governance mechanism on firm performance. Today, the well-known agency problems resulting from the separation of ownership from management still prevail in firms (Jensen and Meckling, 1976). Studies suggest that firms tend to have poor performance when they have greater agency problems and these allow managers to generate personal benefits that serve their own interest instead of those of the stockholders. Hence, an efficient governance structure is believed to be one of the most important means by which such agency problems may be alleviated (Bino and Tomar, 2010).

The Nigerian Banking Sector (Industry) has been strained by the deteriorating quality of its credit assets as a result of the significant dip in equity market indices, global oil prices and the sudden depreciation of naira against global currencies. The Central Bank or Nigeria (CBN) governor in August 142009 intervention speech, identified the industry's significant exposure to the oil and gas and capital market sectors as the major causes of the liquidity constraints that several banks were experiencing. Indications of the 'crisis' became evident in the interbank market where activities diminished as banks responded to the perceived risk of lending to each other. Profits and returns suffered as a result of huge provisioning, while shareholder's equity was haemorrhaged. The development has created liquidity and credit shortages and a crisis of confidence in the nation's financial system (BGL, 2010).

The biggest challenge for bank regulator's in Nigeria is how to get the banks to lend again, entrenching effective and efficient risk management framework, good corporate governance, transparency in reporting e.t.c. For the operators, challenges include infrastructural deficiency, unreliable social data, human capital deficiency, corporate governance issues e.t.c. (BGL, 2010).

Therefore, the purpose of this paper is to examine the impact of corporate governance on financial performance looking at the roles of ownership structure and size of the board of director.

\section{Literature Review}

Corporate governance refers to a set of rules and incentives by which the management of a company is directed and controlled. Good corporate governance maximizes the profitability and long-term value of the firm for shareholders", (Khumani et al., 1998). La Porta, Lopez, and Shleifer (2000) view corporate governance as a set of mechanisms through which outside investors protect themselves against expropriation by insiders, (i.e. the managers and controlling shareholders). They then give specific examples of the different forms of expropriation. The insiders may simply steal the profits; sell the output, the assets or securities of the firm they control to another firm that float they own at below market prices; divert corporate opportunities from firms; put unqualified family members and acquaintances in managerial positions; putting round peg in square hole, or overpay managers. This expropriation is central to the agency problem described by Jensen and Meckling (1976).

Agency theory provides the context within which to discuss the relationship between ownership structure and firm performance. The main issue in the principal-agency literature is centered on asymmetric information because outside owners do not have access to full information on corporate performance or the reasons for under-performance. The separation of ownership and control, which occurs as a result of the introduction of external investors, brings the fore the agency problem (Oyejide and Soyibo, 2001).

These agency problems and weak corporate governance, not only lead to poor firm performance and risky financing patterns, but are also conducive to macroeconomic crises, like the 1997 East Asia crisis (Claessens et al. 2002b). Thus, agency problems and corporate governance in Nigeria call for serious scrutiny. In 2009, the CBN governor sacked and replaced 5 CEOs of prominent and leading banks in Nigeria in the process of reform intended to promote transparency, accountability and the rule of law in the economic life of the country. This initiative was an effort to enhance 
corporate governance in Nigeria. Though series of reform had taken place between 1999 and 2004 through phased capitalization to increase banks minimum share capital

Corporate governance mechanisms can be categorized in two: endogenous mechanisms and exogenous mechanisms.

Endogenous corporate governance mechanism is otherwise known as internal corporate governance. It is about mechanisms for the accountability, monitoring, and control of a firm's management with respect to the use of resources and risk taking (Llewellyn and Sinha, 2000). Internal corporate governance starts with the board of directors which is the supreme governing body of the bank, and is responsible for setting the strategic direction of the bank and overseeing the risk management policies of the bank. The board of directors is appointed by the shareholders of the company. It has the ultimate responsibility for the manner in which the operations/business of a bank is conducted.

A board must be strong, independent and actively involved in the activities of a bank. Although a bank's directors may not be experts in banking, it is important that they have the skills, knowledge, and experience to enable them to perform their duties effectively.

Ciancanelli and Gonzales (2000) state that in the banking sector, the regulation and regulator represent exogenous or external corporate governance mechanisms. In the conventional literature on corporate governance, the market is the only external governance force with the power to discipline the agent. The existence of regulation means there is an additional external force with the power to discipline the agent. This force is quite different from the market. This implies that the power of regulation has different effects to those produced by markets. In Nigeria, the regulators consist of CBN, SEC, NDIC.

Bank regulation represents the existence of interests different from the private interests of the firm. As a governance force, regulation aims to serve the public interests, particularly the interests of the customers of the banking services. The regulator does not have a contractual relationship either with the firm's principal or with the banking organisations because of differing interests from those of the principals (Ciancanelli and Gonzales, 2000).

The role of bank regulators and supervisors in the corporate governance process is mainly seen through the laws and regulations that are promulgated. Such laws pertain to capital adequacy requirements, reserve requirements, assets quality, liquidity, earnings etc. The lessons learnt from financial crisis are to open awareness of the government and business people on the importance of implementing good corporate governance in the financial sector.

There had been many research works supporting there is positive relationship between corporate governance mechanisms of ownership structure, the size of the board and company performance. On ownership structure, Jensen and Meckling (1976) laid out the theoretical relationship between corporate governance and firm performance. They tied together the elements from the theory of agency, theory of property cost and theory of finance, to develop the theory of the ownership structure of the firm. They found as the manager's ownership percentage increases, the firm value will increase as well.

Eldenburg et al., (2004) also look at the impact of ownership structure and hypothesized that differences across ownership types will be associated with differences in boards' objectives and governance. They tested a hypothesis by examining critical actions boards take, the decision to replace the CEO and the extent to which this decision differs across different ownership types. They found that the composition of the board of directors vary according to the differences in ownership structure and leads to differences in both the factors that affect the turnover in the board of directors, and the determinants of CEO turnover.

As for the impact of board of directors (outside directors/board independence) empirical research results are mixed. Some argue for more outside directors and others argue against it. Generally, there appears to be no empirical evidence that the existence of outside directors is correlated with firm performance. However, there is overwhelming empirical evidence on the positive role played by outside directors in board's monitoring and control function. Weisbach (1988) tested whether monitoring management in companies with outsider - dominated board is more effective than for companies with insider - dominated board, by relating CEO resignations to performance measures like stock returns and accounting earnings. He also tested whether the CEO replacement relationship vary depending on a firm's size, ownership structure or industry. He found that the performance measures are more highly correlated with CEO turnover for firms in which outsiders dominate the boards of director than for firms in which insider dominate. The main result of Weisbach (1988) is that the composition of the board is what determined the level of monitoring the CEO, and this level of monitoring is not caused by differences in the ownership structure, the size or the industry of the firm.

Tandelilin, Mahadwartha, and Supriyatha (2007) assert that the central focus of researchers all over the world on matters to do with corporate governance has been the role of ownership structure as corporate governance mechanism. Whether the kind of ownership structure matters and what are its implications for corporate governance are areas that 
raise some concern (Tandelilin et al., 2007). A lot of attention has focused on the relationship between ownership structure and corporation performance. For instance a rich research agenda on the implications of ownership structure on corporate governance by La Portal, Lopez-de-Silanes, Shleifer, and Vishny (2002) affirm that when the legal structure does not offer sufficient protection for outside investors and entrepreneurs, original owners are forced to maintain large positions in their companies which result in a concentrated form of ownership thus having implications on ownership structure. On the other hand, bulk of the evidence according to Shirley and Walsh (2001) indicates that privately held firms are more efficient and more profitable than publicly held ones although the evidence differs on the relative merit of the identity of each private owner.

Regarding board size dimension, Yermack (1996) tested the effect of board size on the performance and management efficiency. The main hypothesis here is that the board size of the firm presents an important determinant of its performance, and that the firm value depends on the quality of monitoring and decision - making by board of directors. He estimated a regression relationship using the ratio of (market value of assets over the replacement cost of assets) as the dependent variable and board size as the most important of the explanatory variables. Other measures of firm value and profitability used by Yermack (1996) include the return on assets and return on sales ratios. All three dependent variable have negative and significant associations with the board size. The main result of this paper is that there is an inverse relationship between board size and firm value. Companies with large boards appear to use assets less efficiently and earn less profit.

Regarding board size dimension, Yermack (1996) tested the effect of board size on the performance and management efficiency. The main hypothesis here is that the board size of the firm presents an important determinant of its performance, and that the firm value depends on the quality of monitoring and decision - making by board of directors. He estimated a regression relationship using the ratio of (market value of assets over the replacement cost of assets) as the dependent variable and board size as the most important of the explanatory variables. Other measures of firm value and profitability used by Yermack (1996) include the return on assets and return on sales ratios. All three dependent variable have negative and significant associations with the board size, and the main result is that there is an inverse relationship between board size and firm value. Companies with large boards appear to use assets less efficiently and earn less profit.

\section{Empirical Evidence of Corporate Governance and Banks Performance}

Empirical evidence on the relationship between corporate governance and performance is mixed. For examples, La Porta, Lopez-de-Silanes, Shleifer, and Vishny (2002) find evidence of higher firm performance in countries with better protection of minority shareholders. Klapper and Love (2003) report that better corporate governance is highly correlated with better operating performance. They also document that firm-level corporate governance provision matter happens more in countries with weak legal environments. Black, Jang, and Kim (2003) provide empirical evidence that there is a positive correlation between corporate governance and performance, but they have no explanation about the causal relationship. Drobetz (2004) also finds that higher corporate governance rating is related to high performance.

However, the above empirical studies are more concerned about examining the differences and correlations than about causal relationships. On the other hand, Drobetz, Schillhofer, and Zimmermann (2003) explore the relationship between firm-level corporate governance and firm performance. They suggest that good corporate governance leads to higher firm valuation (performance), hence, investors are willing to pay a premium, and bad corporate governance is punished in terms of valuation discounts.

Control effectiveness of different types of bank ownerships to moderate the relationships between corporate governance, risk management, and bank performance depend on types of ownerships structure. Types of bank ownerships structure can be classified in different types based on the power of control: shareholders are widely dispersed; a dominant owner who exercises control and appoints management (concentrated); an intermediate case where large shareholders (or called a blockholder) have veto power over major management decisions (Patrick 2001).

Mester (1989) and Mester (1993) document that public-owned banks and mutual banks have slight cost and profit advantages over their private banks. While Altunbas, Evans and Molyneux (2001) also find that there is little evidence to suggest that private owned banks are more efficient than their mutual and state-owned firm counterparts. The results are different from previous evidence provided by O'Hara (1981) and Nichols (1967), suggesting that management of mutual banks is less efficient than management of private-owned banks. On the other hand, La Porta, Lopez-de-Silanes, and Shleifer (2000) provide contradictory empirical evidence.

They mention that state-owned banks are inconsistent with the optimistic "development" theories of government 
ownership of banks common in the 1960s. The results are consistent with the political view of government ownership of firms, including banks, according to which such government ownership politicises the resource allocation process and reduces the efficiency. Lang and So (2002) examine the composition of ownership structures of banks in emerging markets. They observe that foreign banks have higher holdings than do domestic banks if state stakes are excluded. In terms of bank performance, ownership structure has no impacts on the bank performance.

Goldberg, Dages, and Kinney (2000) compare the bank performance of domestic- and foreign-owned banks in Argentina and Mexico. They find that foreign banks generally have higher loan growth rates than do domestic private owned banks which have lower volatility of lending that contributes to lower overall volatility of credit. Additionally, in both of countries according to them, foreign banks show notable credit growth during crisis periods. In Argentina, they maintain the loan portfolios of foreign and domestically private-owned banks are similar and lending rates analogously respond to aggregate demand fluctuations. In Mexico, they found foreign and domestic banks with lower levels of impaired assets have been similar to loan responsiveness and portfolios. State-owned banks (Argentina) and banks with high levels of impaired assets (Mexico) have more stagnant loan growth and weak responsiveness to market signals.

Claessen and Fan (2003) study corporate governance in Asia. They find that agency problems arise from certain ownership structures. Conventional corporate governance mechanisms (through takeovers and boards of directors) are not strong enough to relieve the agency problems in Asia. Firms use other mechanisms to reduce their agency problems (for example, employing reputable auditors), although they have only limited effectiveness. The low transparency of Asian corporations relates to these agency problems and the prevalence of connection-based transactions that motivate all owners and investors to protect rents. The rents often appear from government actions, including a large safety net provided to the financial sector. Forms of crony capitalism (i.e., the combination of weak corporate governance and government interference) are not only leading to poor performance and risky financing patterns but also conducive to macroeconomic crises. Their survey suggests that corporate governance in Asia, including Indonesia, remains unresolved problems, both in conceptual and empirical matters of corporate governance in banking sector.

\section{Empirical Evidence between Board Structure and Bank Performance}

There are many and conflicting empirical findings with respect to board size influence. For instance, Sumner and Webb (2005) argued that the board of directors has the responsibility of formulating bank loan policy and to monitor compliance. Therefore, the structure of the board (proportion of insiders and outsiders) must influence the portfolio of loans that the bank has outstanding. We note however that because financial institutions are monitored by external regulatory agencies, bank boards may not influence loan policy. Their empirical tests using a sample of over 300 US bank holding companies yielded evidence consistent with both positions. For example, they found that both proportion of outsiders and a board strength index are directly related to growth in consumer loans as a percent of total assets, whereas farm and real estate loan holdings are not related to bank board structure.

Pi and Timme (1993) examined the role of the chairman of a bank's board and found that cost efficiency and return on assets are lower for banks that have the same person serving as chairman of the board and chief executive officer (CEO) than for banks without such duality. They also found out that the proportion of insiders/outsiders on the board of directors is unrelated to bank performance. Prowse (1997), among others, examined the power of boards of banks vis-àvis boards of non-financial firms. He found that much of the monitoring responsibility of banks falls on the regulators, not boards. Simpson and Gleason (1999) also find little evidence of corporate governance characteristics influencing bank activity. Kyereboah-Coleman and Biekpe (2006) examined how corporate governance indicators such as board size, board composition and CEO duality impact financing decisions of 47 firms listed on the Nairobi Stock Exchange. They found that firms with larger board sizes employ more debt and the independence of a board correlates negatively and significantly with short-term debts. When a CEO doubles as board chairperson, less debt is employed.

Aboagye and Otieku (2010) studied 30 rural and community banks in Ghana using data over the period 2000 2005 and concluded that an index that captures the state of corporate governance, outreach to clients, dependence on subsidies and use of technology is not statistically associated with their financial performance.

Thus the general objective of the study is to analyse the relationship between corporate governance and performance of Nigeria banking sector. Specifically it attempts to analyse the effect of corporate governance on financial performance of the sector. 


\section{Methodology, Data Analysis, and Discussion}

The study employs basically secondary data from the financial statements of some selected banks in Nigeria. The selection of the banks is due primarily to data availability. Data for the study covers the six year period from 2005 to 2010. The methodological approach used in most previous work examining the impact of corporate governance on firm performance variables utilizes a multiple regression. Thus, the study employs a modified version of the econometric model of Miyajima et al (2003) which is given as follows:

$Y_{i t}=\alpha_{0}+\beta_{1} C G_{i t}+\beta_{2} C_{i t}+e_{i t}$

Where Yit represents firm performance variables; Return on Assets (ROA), for bank i in time t. CGit is a vector of corporate governance variables; Board Size (BDS), Board Composition (BDC=number of outside directors/total number of directors), and e, the error term.Cit is a vector of control variables; Size of the Firm (Size).

\section{Variables and Explanation}

The variables for the study were chosen based on data availability and computational purposes.

\subsection{Firm performance variable}

ROA=this is defined as return on assets and is computed by dividing profits before interest and tax payments by total assets.

\subsection{Governance variables}

BDS=this is the number of members serving on a firm's board;

$\mathrm{BDC}=$ the board composition is the ratio of outside directors to the total number of directors (i.e. number of outside directors divided by total number of directors)

\subsection{Control Variables}

SIZE= this is the size of the firm measured by the value of its asset base. For the regression analysis, we take the log of the assets because the values are widely spread.

The essence of the control variables is to give recognition to the fact that the performance of firms especially banking firms may be influenced by several factors.

The regression is run in a panel manner; various options of panel data regression were run, fixed effects, random effects, OLS and the GLS. The most robust of all was the GLS panel. Thus, we report results of the GLS panel regression.

\section{Data Analysis and Discussion}

The data sets are summarised in Table 1, which provides the summary statistics. The correlation matrix between the variables is also provided in Table II.

Table 1: Descriptive statistics of dependent and independent variables

\begin{tabular}{|l|c|c|c|c|}
\hline \multicolumn{1}{|c|}{ Variables } & Mean & Standard deviation & minimum & maximum \\
\hline Roa & 2.2195 & 1.1012 & 0 & 3.48 \\
\hline Asset & 12.08 & 4.185 & 0 & 14.51 \\
\hline Boardsize & 16.2 & 1.989 & 15 & 20 \\
\hline Number Of Executive Director & 8 & 1.71679 & 5 & 10 \\
\hline Number Of Non Executive Director & 8.2 & 1.989 & 6 & 11 \\
\hline Board Composition & 0.504 & 0.099 & 0.4 & 0.6875 \\
\hline
\end{tabular}

Of the banks studied, the mean board size is about sixteen (16) suggesting that banks in Nigeria have relatively moderate board sizes with a maximum board size of twenty (20) and deviation of 1.98, implying that banks in Nigeria have relatively similar board sizes. The descriptive for the board composition is however low suggesting that the ratio of outside directors 
to the total number of directors in Nigeria banks is low.

Table 2: Correlation matrix of the variables

\begin{tabular}{|l|c|c|c|c|c|c|}
\hline \multicolumn{1}{|c|}{ Variables } & Roa & Asset & Boardsiz & $\begin{array}{c}\text { Number Of } \\
\text { Executive }\end{array}$ & $\begin{array}{c}\text { Number Of Non } \\
\text { Executive Director }\end{array}$ & $\begin{array}{c}\text { Board } \\
\text { Composition }\end{array}$ \\
\hline Roa & 1.000 & & & & & \\
\hline Asset & 0.6883 & 1.000 & & & & \\
\hline Boardsize & -0.3063 & -0.2604 & 1.000 & & & \\
\hline Number Of Executive Director & 0.1793 & 0.1543 & 0.4315 & 1.000 & & \\
\hline $\begin{array}{l}\text { Number Of Non Executive } \\
\text { Director }\end{array}$ & -0.4610 & -0.3935 & 0.6277 & -0.4315 & 1.000 & 1.000 \\
\hline Board Composition & -0.3972 & -0.3348 & 0.1723 & -0.8142 & 0.8749 & \\
\hline
\end{tabular}

The estimation results are presented in Tables III. The variable of number of non executive directors was removed because of collinearity. This is indicated in the correlation matrix result in Table II above. Overall, the $R^{2}, 0.685$, suggests high predictive ability of the remaining independent variables. The value indicates that all the included explanatory variables account for about 69 per cent of the variations in the performance of banking industry. Total asset is positive and statistically significant at 5 per cent, indicating that higher total asset has a direct and positive effect on the performance of the banking sector. Board size is positive and significant at 5 per cent level. The result indicates that increase in board size would increase the performance of the bank.

Contrary to studies by Yermack (1996), the study show that the lager the size of the board, the better the performance. This confirms studies that support the view that larger boards are better for corporate performance because members have a range of expertise to help make better decisions, and are harder for a powerful CEO to dominate and that the larger the size of the board, the better the performance.

However, the coefficient of both numbers of executive directors and board composition is negative but significant at 5 per cent. The result indicates that improved performance of the banking sector is not dependent on increasing the number of executive directors and board composition.

The negative coefficient associated with board composition implies that when there are more external board members, performance of the banks tends to be worse. The result is however consistent with findings by Agrawal \& Knoeber (1996) who suggest that boards expanded for political reasons often result in too many outsiders on the board, which does not help performance.

Table 3: Corporate Governance and Performance

\begin{tabular}{|l|c|c|}
\hline \multicolumn{1}{|c|}{ Variables } & Coefficient & Standard Error \\
\hline Total asset & $0.1699817^{*}$ & .0416824 \\
\hline Board size & $11.7227^{*}$ & 4.180932 \\
\hline Number of executive directors & $-23.17194^{*}$ & 8.216077 \\
\hline Board composition & $-366.8878^{*}$ & 129.409 \\
\hline Constant & 180.6065 & 63.22 \\
\hline \multicolumn{2}{|c|}{} \\
\hline \multicolumn{2}{|c|}{$\mathrm{R}^{2}=0.6853$} \\
\hline
\end{tabular}

Source: Field Survey, 2013, *, significant at 5 per cent

\section{Conclusion}

The importance of corporate governance in enhancing the banks' organizational climate for performance is significant. Corporate governance brings to bear through external independent directors, new dimension for effective running of a corporate entity thereby enhancing a bank's corporate entrepreneurship and competitiveness.

The study examined the relationship between some measures of corporate governance such as board size, board composition, and firm performance of selected banking institutions in Nigeria. The findings indicate a need for increase in board size and decrease in board composition as measured by the ratio of outside directors to the total number of directors in order to increase the bank performance. 


\section{References}

Agrawal, A. \& Knoeber, C. R. (1996). Firm Performance and mechanism to control agency problems between managers and shareholders. Journal of Financial and Quantitative Analysis, vol. 31, pp. 377-397

Altunbas, Y. L. Evans and Molyneux, P. (2001). Bank Ownership and Efficiency. Journal of Money, Credit and Banking. 33, 926-954.

BGL, (2010). BGL Banking Report. January.

Bino, A. and Tomma, S, (2010). Corporate Governance and Bank Performance: Evidence from Jordanian Banking Industry. www.ju.edu.jo/Resources/Economic Observation/ Lists/Conferences. Jan 27

Black, B., Jang, H. \& Kim, W. (2003). Does Corporate Governance Affect Firm Value? Working paper 327, Stanford Law School.

Ciancanelli, P. \& Gonzalez, J.A.R. (2000). Corporate Governance in Banking: A Conceptual Framework, Social Science Research Network, Electronic Paper Collection: http://www.papers.ssrn.com/paper.taf

Claessens, S. and Joseph P.H.F., (2003). Corporate Governance in Asia: A Survey, Working Paper, Finance Group. University of Amsterdam, Roetersstraat Amsterdam.

Drobetz, W.A.S. and Zimmermann, H. (2003). Corporate Governance and Expected Stock Returns: The Base of Germany, Working paper, University of Basel.

Drobetz, W. (2004). The Impact of Corporate Governance on Firm Performance, Working Paper, Department of Corporate Finance, University of Basel.

Eldenburg, L. and Hermalin, E. and Weisbach, M. and Wasinska, M. (2004), Governance, performance objectives and organizational form: evidence from hospitals, Journal of Corporate Financial, 10, 527-548

Financial Times, (1999)

Goldberg, L.B., Gerard D. and Daniel, K. (2000). Foreign and Domestic Bank Participation in Emerging Markets: Lessons From Mexico And Argentina, Working Paper 7714, May, http://www.nber.org/papers/

Jensen, M. C. \& Meckling, W. H. (1976). Theory of the Firm: Managerial Behaviour, Agency Costs, and Ownership Structure, Journal of Financial Economics, vol 3, pp. 305-350.

Kaheeru, V (2001) Institute of Corporate Governance of Uganda, Manual.

Kibirango, L. (Sept. /Dec 2002). Capital markets. The Journal for the Capital Markets Industry, Uganda, Vol. 5 No. 4.

Klapper, L. F., and I. Love, 2003, Corporate Governance, Investor Protection, and Performance in Emerging Markets, Journal of Corporate Finance 195, 1-26.

Kyereboah-Coleman, A. \& Biekpe, N. (2005). Corporate Governance and the Performance of Microfinance Institutions (MFIs) in Ghana. Working Paper, UGBS, Legon.

La Porta, R., Lopez-de-Silanes F., Shleifer A., \& Vishny, R., (2000). Investor Protection and Corporate Valuation. Journal of Finance, Vol. 57, pp. 1147-1170. doi:10.1111/1540-6261.00457, http://dx.doi.org/

La Porta, R., Lopez-de-Silanes F., Shleifer A., \& Vishny, R., (2002). Investor Protection and Corporate Governance. Journal of Financial Economics, Vol. 58, pp. 3-27. doi:10.1016/S0304-405X(00)00065-9, http://dx.doi.org/

Lang, L. H. P. \& So, R. W. (2002). Bank ownership structure and economic performance, working paper, Department of Finance, Chinese University of Hongkong. Shatin: Hong Kong.

Llewellyn, David, and Rajeeva Sinha, (2000), Monitoring and Control of Banks: The Role of Regulation and Corporate Governance, in the book of Corporate Governance in Banking and Finance, Edited by Y.R.K Reddy and Yerram Raju, Tata McGraw-Hill Publishing Co. Ltd., New Delhi.

Matama, R. (2008). Corporate Governance and Financial Performance of selected Commercial Banks in Uganda. CRRC. 7 to 9 September. Http:www.crrconference.org.

Mester, L.J., (1989), Testing for Expense Preference Behavior: Mutual versus Stock Savings and Loans, Rand Journal of Economics 20 , 483-498.

Mester, L.J., (1993), Efficiency in the Savings and Loan Industry, Journal of Banking and Finance 17, 267-286.

Miyajima, H., Y. Omi and N. Saito (2003) "Corporate Governance and Performance in Twentieth Century Japan" Business and Economic History Vol. 1, 1-36

Nichols, A., (1967), Property Rights and Behavior: Stock versus mutual savings and Loan Associations: Some Evidence of Differences in Behavior, American Economic Review 57, 337-346.

O'Hara, M. (1981). Property Rights and The Financial Firm. Journal of Law and Economics 24, 313-333.

Patrick, H. (2001). Corporate Governance, Ownership Structure and Financial Crisis: Experience of East Asian Countries, Working Paper, KDIC International Financial Symposium, The Financial Crisis and Beyond, Seoul, December 11.

Prowse, S. (1997), 'Corporate Control in Commercial Banks', Journal of Financial Research, Vol. 20, pp. 509-527

Shleifer, A. \& Vishny, R. (1997). A survey of Corporate Governance. Journal of Finance 52: 737-783.

Simpson, W. G., and A.E. Gleason (1999), 'Board Structure, Ownership, and Financial Distress in Banking Firms', International Review of Economics and Finance, Vol. 8, pp. 281-292.

Tandelilin, E., Kaaro, H., Mahadwartha, P. A. \& Supriyatna. (2007). Corporate Governance, Risk Management and Bank Performance: Does Type of Ownership Matter? EADN Working Paper No. 34.

Weisbach, M. (1988), Outside directors and CEO turnover, Journal of Financial Economics, 20, 431-460.

Yermack, D. (1996). Higher market valuation of companies with a small board of directors. Journal of Financial Economics 40: $185-211$. 